\title{
Corporate Governance and Investors' Decision in Quoted Deposit Money Bank in Nigeria
}

\author{
Aimonomhe Jafaru Marughu and Appolos Nwabuisi Nwaobia
}

\begin{abstract}
Investment decision involves risk and uncertainty. An investor makes the choice of where and what to commit funds into for future returns. Studies have shown that due to pressure to satisfy investors' desire and to make their company attractive to investors, corporate managers manipulate financial books and pay dividends to shareholders on profits not earned. This practice may lead to wrong investment decisions by investors. This study examined corporate governance and investors' decision in quoted deposit money banks in Nigeria.

Ex-post facto research design was employed. The research population comprised the fifteen deposit money banks quoted on the Nigerian Stock Exchange as of December 31, 2017. Total enumeration method was used. Validated data were obtained from the Nigerian Stock Exchange and audited financial statements of the sampled deposit money banks. The data were analyzed using descriptive and inferential statistics.

Results indicated that corporate governance proxies of board size, board composition and audit quality jointly had a significant and positive effect on volume of shares traded $\left(F(4,130)=13.43 ;\right.$ Adj. $\left.R^{2}=0.0753 ; p=0.0093\right)$; corporate governance and control variables of firm size and profitability had a joint and positive effect on volume of shares traded $\left(F(6,126)=20.15 ;\right.$ Adj. $\left.R^{2}=0.0654 ; p=0.0026\right)$.

The study concluded that corporate governance affects volume of shares traded and firm size and profitability of firms have controlling influence on volume of shares traded. Management and board of directors should imbibe transparent corporate governance culture in their organizations to attract investors when making investment decision.
\end{abstract}

Index Terms - Audit committee expertise, Audit quality, Board composition, Board size, Corporate governance.

\section{INTRODUCTION}

Investment decisions involve risk and uncertainty. This implies that investment can either yield the desired expectation or result to loss of fund. Owing to the risky nature of investment, an investor should carry out due diligence on every investment opportunity. Investors are faced with decisions that must be made under different degrees of uncertainties and risks. Masomi and Ghayekhloo [1] concluded that faced with several choices, an investor making investment decision will prefer alternative with higher benefit. Olafsson [2], reported that investment decision is typically about managing these future occurrences and knowing the relationship between the risks and the opportunities.

Pandey [3] agreed that investment decisions are based on the assumption that an investor should only consider the

Published on November 11, 2020.

Aimonomhe Jafaru Marughu, Department of Accounting, School of Management Sciences, Babcock University, Nigeria.

(corresponding e-mail: marughu@ ${ }^{@}$ yahoo.com) decision that maximize the market value of the share or the shareholders' wealth. The objective of a shareholder is to earn a return on his investment [4]. The market value of share is treated as an indicator of efficiency and effectiveness of the firm [5]. Investors will usually prefer investment with lower share price at the point of investing which in the long run, will result to higher value in the market. Due to pressure to satisfy investors' desires and to make their company attractive to investors, corporate managers manipulate financial books and pay dividends on profit not earned. Onyenankeya [6], noted that the practices of altering the figures in the financial statements to make them look good gives a wrong financial status of the organization to recipients of the reports. This practice may lead to wrong investment decisions by investors who place premium on profitability as a determinant in their investment decisions.

Major corporate institutions in the USA, South East Asia and Europe such as Adelphia, Enron, World Com, Commerce Bank and XL Holidays have collapsed due to manipulation of their financial statements. The fall of these corporate giants shook investors' confidence in the capital markets [4], [7]. Their collapse was attributed to poor corporate governance and unethical practices [8]. Nigeria was not immune from the corporate scandals. In 1997, the financial statement of Lever Brothers was manipulated to show that the company made profit whereas the company sustained a huge loss [9], [10]. Fabian [11] pointed out that a notable incident was that of Cadbury Nigeria Plc where Securities and Exchange Commission had to conduct an investigation into allegation of overstatement of earnings to the tune of N13.25 billion. Intercontinental Bank Plc and Oceanic Bank Plc which were hitherto doing well in the Nigeria capital market also collapsed for the same reason of manipulation of books and disregard to corporate governance [4].

Owolabi [8] opined that the "financial performance shown by banks should normally attract investors but due to financial manipulation of these figures, reliance on them may be inappropriate." Owolabi [8] concluded that investors should be careful when relying on the figures in the financial statement without carrying out due diligence on the level of compliance to corporate governance standards and principles by companies of their choice. Vogel [12] revealed that what investors want from their investments has continued to increase daily and that while investors expect maximum returns from firms, they have also realized the importance of corporate governance in helping them maximum the value and volume of their investments. 
Corporate governance refers to the structure and processes for the direction and control of organizations. The International Finance Corporation [13] explained that it concerns the relationships existing among the stakeholders of an organization which include management, board of directors, shareholders, and other stakeholders. Corporate governance is about transparent, effective, and accountable governance of the affairs of an organization by its management and board. It is about decision-making process that holds individuals accountable for their actions and inactions. It encourages stakeholders' participation and facilitates the flow of information. Good corporate governance is about holding the balance between economic and social goals, and between individual and communal goals [14]. According to Surya [15], corporate governance involves a set of relationship between a company's management, its board, shareholders, and other stakeholders. The IFC [13] noted that good corporate governance contributes to sustainable economic growth and development by enhancing the performance of companies and increasing their access to outside capital.

Despite the recognition of the concept of corporate governance globally, its adoption has been reactionary. The dramatic collapse of the two energy giants, Enron and WorldCom and the relegation of another renowned auditing and accountancy firm, Arthur Andersen, owing to its role in the scam involving Enron led to the introduction of Sarbanes Oxley Act in 2002 which placed the ultimate responsibilities of corporate governance on the Chief Executive officer [16]. In the United Kingdom, government reacted to the corporate scandals that rocked the big corporations such as WorldCom and Enron by establishing the Financial Reporting Council (FRC). Cadbury Committee was also set up. According to FRC, the Committee's report produced the Code of Best Practice which U.K listed companies were required to comply with.

In Nigeria, the need to have a code of corporate governance was recognized following the Lever Brothers scandal. The Securities and Exchange Commission (SEC) Committee was established. The Committee developed Nigeria's first code of corporate governance in 2003. Other industry specific (sectoral) codes have been established such as Code of Corporate Governance for banks in Nigeria post consolidation 2006 issued by $\mathrm{CBN}$, Code of Corporate Governance for licensed Pensions Operators 2008 issued by the Pensions Commission and Code of Corporate Governance for insurance industry in Nigeria 2009 issued by the National Insurance Commission (NAICOM) and more recently, in 2018 the Nigerian Code of Corporate Governance was issued by the Financial Reporting Council of Nigeria.

On November 3 2014, the Nigerian Stock Exchange (NSE) launched the Corporate Governance Rating System (CGRS). The CGRS is meant to encourage the adoption of sound governance principles by organizations towards promoting and sustaining long term performance of listed companies in the Nigeria capital market. As on November 2014, when CGRS was launched, eight companies submitted themselves for evaluation. As on December 2019, thirty-three companies have been evaluated and awarded CGRS certificates while 435 directors of listed companies have passed the CGRS rating. Onyema [17], submitted that the adoption of sound corporate governance principle will determine the attractiveness of listed companies to local and foreign investors. Also, on $22^{\text {nd }}$ February 2018, the NSE also launched the Corporate Governance Index. Onyema [18] explained that the objectives of having a Corporate Governance Index are to raise the national corporate governance ceiling by supplementing the existing national corporate governance framework of law, regulation and code, to give companies the opportunity to differentiate themselves by showing good corporate governance practices and to gain access to funds committed to good corporate governance practice and sustainability.

The researcher came across limited studies on corporate governance and investors' decision in quoted deposit money banks in Nigeria. Several empirical studies carried out within and outside Nigeria focused on investigating the relationship between corporate governance and firm's performance. These include Khaliq and Mohammed [19], Surya [15], Ferreira [20], Adekunle and Aghedo [21]. Agbaeze and Ogosi [22] on their part examined the impact of corporate governance and profitability of Nigerian banks for the period 2005 and 2015, using data from a small sample of five banks out of the population of 21 banks that were operating at the time of the study.

This study is timely and fills the identified gap of dearth in literature in the area of corporate governance and investors decision in quoted deposit money bank in Nigeria. The rest of this paper is organized as follows. Section two reviews existing literature and highlights the theoretical framework underpinning the study. Section three presents the methodology of the study and measurement of variables. Section four presents the results and discussions while conclusion and recommendations are presented in section five.

\section{LITERATURE REVIEW}

\section{A. Conceptual Review}

\section{Investors' Decision}

Investors' decision is the thought process of selecting an investment option from available alternatives. It is the process of weighing the positives and negatives of each alternative and choosing the best option for that situation. An investor makes the choice of where and what to commit funds into for future return depending on his risk tolerance. Slater and Zwirlein [23] posited that investment decisions follow the pattern of modern financial theory which states that only investment with positive net present value should be undertaken.

Investments are fraught with uncertainties and risks which if not properly dimensioned from the onset can result to loss of funds. A wrong decision can result to loss of invested funds. In the view of Okere and Ibidunni [24] investment decision making is a crucial activity for investors, especially in the volatile environment with multidimensional alternatives. Okere and Ibidunni [24] advised investors to be vigilant and updated if they must achieve the desired goal. Olafsson [2] posited that the process of managing the uncertainties associated with investment and understanding the connection between the risks and prospects is what 
investment decision is about. Masomi and Ghayekhloo [1] observed that decision makers are rational and utility maximizing. The need to reduce the uncertainties associated with future outcomes of present decision makes investment decision desirably necessary.

\section{Volume of Shares Traded}

Volume of shares is the total quantity of shares traded on a particular security during a specified period of time [25]. Volume of shares includes the total number of shares transacted between a buyer and a seller during a transaction. Mohammed and Elewa [26] wrote that firms with strong corporate governance experience a significant positive impact on trade volume. Mohammed and Elewa [26] further said that volume of shares traded is significant as it tells the investors about the market's activity and the liquidity of the market and the particular stock. According to them, higher trade volume signifies higher liquidity.

\section{Corporate Governance}

Corporate governance has been in the spotlight in developed economies following the collapse of the corporate giants like Enron, WorldCom, Adelphia, Ahold Foodservices. In Nigeria, the collapse of some big deposit money banks such as Intercontinental bank and Oceanic bank; and the discovery of overstatement of earnings to the tune of N13.5 billion by the management of Cadbury Nigeria Plc raised the question of the role of corporate governance [27]. Different writers, authors and researchers have given their definitions of what corporate governance is based on their experience, focus and expectation [21], [28]-[30]. In the view of Ramon [31], it is difficult to define the concept of corporate governance in a universally acceptable way because definitions vary from country to country. Moreover, countries differ from each other in terms of culture, legal system, and historical development. This explains why there is a wide range of definitions of the concept of corporate governance.

Corporate governance refers to the relationship existing among shareholders, board of directors and top management in determining the direction and success of the corporation [32]. Corporate governance brings about harmonious coexistence for the attainment of organization's objectives. It is aimed at protecting weak and widely dispersed shareholders against self-interested directors and managers. The conclusion made by Ekundayo [27] is that "Corporate governance is a matter of much greater importance in public companies where separation of ownership from management is much wider than in private companies where owners actively participate in the day to day running of the companies hence the challenge of good corporate governance is to find a way in which the interest of shareholders, directors and other stakeholders can be sufficiently protected and satisfied." This is because managers who are entrusted with the resources of the organization may be pursuing their personal goals. Fama and Jensen [33] explained that in this situation, managers have superior access to inside information and the relatively powerless position of the numerous and dispersed shareholders mean that managers are likely to have the upper hand.

Adekunle and Aghedo [21] posited that "corporate governance is all about running an organization in a way that guarantees that its owners as stakeholders are receiving a fair return on their investment." Corporate governance promotes accountability that engenders trust and reliability. In the view of Clarkson and Deck [34], corporate governance is the process of a virtuous circle that links the shareholders to the board, to the management, to the staff, to the customer and to the community at large. Clarkson and Deck [34] concluded that an incorporated company assumed the status of a legal entity having natural existence.

Corporate governance is about equity, probity, fairness, accountability, and transparency in dealing with an organization's resources. Okeahalam and Akinboade [35] outlined specific benefits of corporate governance to include "moral uprightness among organization workforce and it could be counted upon to safeguard the resource and entitlements of all stakeholders. Also, it improves the confidence of the investing public and attracts local and foreign investors to the companies in particular and the economy in general."

\section{Profitability}

Investors are rational in their investment decisions hence performance is a first consideration when making investment decision. According to Agbaeze and Ogosi [22] "effective and efficient corporate governance tend to improve how organizations discharge their corporate and statutory responsibilities and substantially affects their overall performance." Good corporate governance is necessary in attracting investors and improving efficiency which invariably leads to better performance and aid decision making [17], [18]. In the area of attracting investors, Agbaeze and Ogosi [22] supported the view of McGee [36] that companies with poor corporate governance practices will not attract foreign capital and their shares will not also be attractive in the international markets.

\section{Firm Size}

Firm size has become a common control variable used in research. Some researches proxied firm size with the number of employees while others use value of assets. Recent researches used total assets, total sales and number of employees as proxies in determining the relationship between firm size and profitability. Babalola [37] noted that "the size of a firm plays an important role in determining the kind of relationship the firm enjoys within and outside its operating environment."

Jelic, Briston and Aussengg [38] and Kakani, Saha and Reddy [39] explained the importance of scale economies and other efficiencies in larger firms. Dogan [40] found a positive association between firm size and profitability. Majumdar [41] investigated the impact of firm size on profitability and productivity of a firm using a sample of 1,020 Indian firms. He controlled other variables that could have influence on the performance of a firm. The result revealed that larger firms are less productive but more profitable. Babalola [37] noted that "some studies find a positive impact while others find negative or no relationship between firm size and profitability." That is why Babalola [37] concluded that there has not been an agreement on the connection between the size of a firm and its profitability.

\section{Corporate Governance Mechanisms}

6.1. Board Size

Adekunle and Aghedo [22] argued that "there is a convergence of agreement on the argument that board size is 
associated with firm performance." Different views as to the right size of board that will improve the performance of a firm or makes the board ineffective exist. Lipton and Lorsch [42] argued that boards with large members can be cumbersome and can easily be manipulated and controlled by the CEO. In effect, when a board is too large, it becomes difficult to coordinate and for it to process and handle strategic problems of the organisation. Yermack [43] believed that because of the divergent views associated with larger boards, decision making may not be fast. Lipton and Lorsch [42] said when board becomes too big, agency problems such as director free-riding increase within the board and the board becomes more symbolic and less a part of the management process. The advantage of larger board size is the greater collective information that the board subsequently possesses, and hence larger boards will lead to higher performance [44], [45]. Large boards provide pool of knowledge, skills, and expertise, reduce the dominance of an overbearing Chief Executive Officer, and entrenches necessary check and balance in the organization [7]. Jensen [46] enumerated the problems with large boards to include co-ordination cost and delay in decision making because it take time to hold board meetings. The disadvantages of larger boards are difficulty in co-ordinating, prone to coalition which could affect the effective running and the provision of oversight role of the board, co-ordination problems because it could be more difficult to arrange board meetings which may slow down decision making and lack of common purpose which affects board cohesiveness [15]. Yermack [43] found negative correlation between board size and profitability. On their part, Sanda, Mikailu and Garba [47] reported that firm performance is positively correlated with small as opposed to large boards. There is however a limit to the number of board membership. To enhance efficiency and effectiveness, the board size ought to be relative to the size of the firm. The choice of the size of board to adopt will however depend on the company based on its experience.

\subsection{Board Composition}

This is taken as the proportion of independent directors and institutional investors as member of the board against total number of directors. Hermalin and Weisbach [48] did not find see any major relationship between the composition of the board and performance. Studies that reported negative effect of independent directors on firm performance include Yermack [43], Klein [49] and Bhagat and Bolton [50].

$\mathrm{Li}$ and $\mathrm{Li} \mathrm{[51]} \mathrm{posited} \mathrm{that} \mathrm{institutional} \mathrm{investors} \mathrm{have} \mathrm{the}$ advantages of professional information and financial knowledge involved in corporate governance, improving corporate governance through internal and external mechanism. As the number of institutional investor membership increases in a firm's board, so also is professionalism and dynamism increase. According to Hartzell and Starks [52], institutional investors play an effective supervisory role on the payment contracts of managers. They found that concentration of institutional investors was positively correlated with performance pay sensitivity in managerial compensation and negatively correlated with managerial abnormal return.

\subsection{Audit Quality}

Audit quality from the technical point of view is about the auditor meeting the consumer expectation in the areas of reporting errors and irregularities. DeAngelo [53] sees audit quality as the favourable assessment by the audit market that the auditor will detect irregularities in the clients' accounting system and bring such irregularities to light. Palmrose [54] defined audit quality in terms of the auditor accreditation. The auditor's aim is to ensure that the financial statement is reliable. Audit quality therefore means the audited financial statement being free from material misstatement.

\subsection{Audit Committee Expertise}

Section 404(3- 4) of CAMA, 2020 states that the audit Committee "shall consist of five members comprising of three members and two non-executive directors. They shall examine the auditors' report and make recommendations thereon to the annual general meeting as it may deem fit." The primary purpose of an audit committee is to provide oversight of the financial reporting process, the audit process, the system of internal controls and compliance with laws and regulations.

Empirical works have revealed that audit committee financial experts is associated with less earnings management, fewer restatements, and lower cost of debt [55][58]. Other studies found a significant positive stock price reaction when a financial expert is added to the audit committee [59], [60]. In the contrary, Salehi, Moradi, and Paiydarmaneshi [61] concluded that the presence or absence of audit committee in companies has no effect on corporate governance.

Klein [62] did not find any effect of audit committee on firm's performance. Klein [62] noted that corporate governance and audit committee has a negative relationship. Baxter and Cotter [63], in contrast to Klein [62] documented that the presence of audit committee play a role in reducing earnings management. Hamdan, Sameh and Reyed [64] observed that audit committee characteristics have major impact on stock and financial performance.

Alzoubi [65] and Ammar, Muhammad and Muhammad [66] believed that firms audited by the Big 4 auditors have lower levels of earnings management than firms audited by non-Big 4 auditors. According to them, firms audited by the Big 4 have lower earnings management because such audits have mostly been carried out in the United States and other countries where auditors face a high litigation risk from shareholders if they provide a lower quality audit.

\section{B. Theoretical Framework}

This study adopted the agency theory popularized by Jensen and Meckling in 1976 [67] and stakeholder theory propounded by Edward Freeman [68]. The agency theory explained that one party known as the shareholders provide the work to be done while the other party known as the agent carries out the work for a remuneration. The theory further argued that shareholders' interest require protection by separation of incumbency of roles of board chair and chief executive officer (CEO). The agency relationship brings about agency costs which the shareholders have to carry. The explanation of the stakeholder theory is that apart from the shareholders, there are other stakeholders who the activities of the organization directly or indirectly affect hence their rights should be protected. The theory argues that a firm should not only consider its shareholders in its value creation but for all the stakeholders. 
Applying these theories to the study, agency costs are the costs that the shareholders incur by having managers run the company on their behalf instead of running the company themselves [69]. The implication of stakeholders' theory is that the actions of other stakeholders could have grave consequence on the survival of an organization, and this will impact on investors' decision.

\section{Empirical Review}

In order to establish the relationship between corporate governance and investors' decision, several related studies that have been carried out in the developed and developing economies by researchers, scholars and academicians were reviewed. These studies were carried out at different times and with different viewpoints and opinions.

\section{Corporate Governance and Investors' Decision}

Investment decisions are made by investors and investment managers [70]. Ambrose and Mutswenje [70] in their research on factors influencing investment decisions found out that investors commonly perform investment analysis by making use of fundamental analysis, technical analysis and judgement. According to Reena [71], investors choose avenues, depending upon their specific need, risk appetite and expected return. Ambrose and Mutswenje [70] concluded that no matter how much an investor is well informed, has done research, studied deeply about the stock before investing, he also behaves irrationally with the fear of loss in the future.

Ferreira [20] researched on corporate governance and its influence on the investment decision process of equity market professionals: An inside view of how corporate governance influences the decision process of sell-side and buy-side professionals when analyzing Brazilian listed companies. The results suggested that there is no one answer, as to the degree of influence that corporate governance will have on investment decision process. According to Ferreira [20], the only certainty is the need to present a corporate governance behaviour rather than simply establishing rules and regulations at firm and country level.

Bistrova, Lace and Tvaronaviciene [72] Investigated the importance of corporate governance to achieve long-term shareholder value within the Central and Eastern European stock markets universe. The results noted that corporate governance is important as evidence showed that market outperformers have above average corporate governance principles and provided reliable financial results than underperforming companies.

Obamuyi [73] evaluated the factors influencing investment decisions in capital market, a study of individual investors in Nigerian capital market. The study revealed that the most influencing factors on investment decisions of investors in Nigeria are past performance of the company's stock, expected stock split/capital increases/bonus, dividend policy, expected corporate earnings and get-rich-quick. The study revealed that age, gender, marital status, and educational qualifications influenced the investment decisions of investors in Nigeria. With regard to the past performance of the company's stock as an assessing factor, Obamuyi [73] said groups of investors statistically differed in factor assessment, as segments of a group considered the factor as the most important/unimportant. The study recommended that the capital market be organized and that attractive policies and programmes which will attract investors and aid them in making investment decisions be proactively and consistently introduced to the market on a timely manner such that investors' investment will be maximized.

\section{Corporate Governance and Volume of Shares Traded}

Volume of shares is the total quantity of shares traded on a particular security during a specified period of time [25]. Collince [74] explained that trade volume is used to determine the activity in a company's share on any given day. When trade volume is high, it shows the attractiveness of the shares to investors at the market price. Llorente, Guillermo, Roni, Gideon \& Jiang [75] submitted that trade volume can result from the hedging and speculative activities of investors.

Tauchen and Pitts [76] explained that trade volume show the degree of belief investors has on the company and is used to judge performance. De Medeiro, Doornik and Bernardus [77] investigated the empirical relationship between stock returns, return volatility and trading volume in Brazilian stock market and found that good governance principles significantly affect stock returns and trading volume. Mohammed and Elewa [26] noted that "strong corporate governance has significant impact on stock price while no significant impact on trade volume." According to Mohammed and Elewa [26] "Quality of corporate governance can affect firm's stock price while trading volume is not affected by the strength of corporate governance"

Dumitrescu [78] investigated the relationship between corporate governance and market liquidity. The investigation revealed that corporate governance has the strength to affect market liquidity. Foo and Zain [79] supported the findings in Dumitrescu [78] that corporate governance variables of board independence and board diligence can influence stock liquidity.

\section{Firm Size as Moderator of Corporate Governance and} Volume of Shares Traded

According to Babalola [37], "the size of a firm plays an important role in determining the kind of relationship the firm enjoys within and outside its operating environment. The larger a firm is, the greater the influence it has on its stakeholders." Obigbemi, Iyoha and Ojeka [80] submitted that "the size of a business enterprise affects different things in the business such as the goodwill, customer loyalty, patronage as well as its level of responsiveness to the stakeholders." The size of a business will determine the shareholder base as well as the capital base of the business which informs the level of stewardship expected from the managers of the business and the board of directors. Owing to the cost involve in publishing financial reports, "small size company may not necessarily publish its reports and when this is done, it may be as a result of the statutory requirements [80]. This view is in agreement with Umoren and Okougbo [81] who noted that "corporate managers are usually reluctant to give detailed information about a non-profitable outlet or product." Wahyuni [82] opined that a company size is one indicator used by investors in assessing the company's assets and its performance. The total assets of a company are relatively used to determine its size. Many lenders are disposed to lending to companies with large asset base because of the belief that if the companies are liquidated, their assets can be sold, and the proceeds used to pay off their debts. 
Jelic, Briston and Aussengg [38] and Kakani, Saha and Reddy [39] explained the importance of scale economies and other efficiencies in larger firms. Baumol [83] argues that the advantages of larger firms stem from their market power and greater access to capital markets. In a related study, Simon [84] did not find any significant relationship between firm size and profitability unlike Hall and Weiss [85] who observed a positive relationship between firm size and profitability in the study they carried out on Fortune 500 firms. Also, Whittington [86] posited that firm's profitability is independent from its size. The study of Chandler [87] reveals that large firms produce products at low costs because of economies of scale, therefore this stratify incline the profitability of the firm. Ravenscraft \& Scherer [88] concluded that because larger firms have greater production capacity, greater stability and generate bumper sales, they command cost savings and economics of scale.

4. Profitability as Moderator of Corporate Governance and Volume of Shares Traded

Profitability is proxied by return on assets of the firm. Investors are rational in their investment decision hence performance is a first consideration when making investment decision. Good corporate governance is necessary in attracting investors and improving efficiency which invariably leads to better performance and aid decision making.

Prusty and Ah-ahdal [89] and Tabash, Yahya and Akhtar [90] opined that profitability is the consistent accomplishment of the financial objectives which a company has set before it. Profitability is a measurement tool used to gauge a firm's overall financial health over a given period of time. It assists investors to compare the performance of similar firms across the same industry in choosing where to invest. Tabash et al. [90] sees profitability as a measure of the results of a firm's policies and operations in monetary terms. Prusty and Ah-ahdal [89] added that investors are attracted to organizations with good corporate governance because of the belief that that their investment will be protected in such organizations.

Rashid, Muhammad and Muhammad [91] believed that effective disclosure of corporate governance practices leads firm towards profitability and growth. They attributed the big corporate collapse such as Enron and WorldCom to poor standard of disclosure in their financial statements and highlighted the importance of disclosure aspect in the body of main research stream.

Based on the above divergent views and result of findings, this study proposed the hypotheses that:

(i) Ho1: Corporate governance does not have significant effect on the volume of shares traded.

(ii) $\mathbf{H}_{0}$ 2: Firm size and profitability do not significantly control the effect of corporate governance on the volume of shares traded.

\section{METHODOLOGY}

\section{A. Research Design}

The study adopted Ex-post facto research design. Kerlinger and Rint [92] explained that in the context of social science research an ex-post -facto investigation seeks to reveal possible relationships by observing an existing condition or state of affairs and searching back in time for plausible contributing factors. This approach was adopted to enable the researcher to obtain existing data which have already been generated.

\section{B. Population of the Study and Sampling Technique}

The research population consisted of fifteen quoted deposit money banks on the Nigerian Stock Exchange as on $31^{\text {st }}$ December 2017. Quoted deposit money banks were chosen as samples because they have the required information, and their financial statements are readily assessable. The study used total enumeration. A ten-year data (2008 to 2017) was obtained from the Nigerian Stock Exchange and audited and published financial statements of deposit money banks in Nigeria.

\section{Method of Data Analysis and Estimation Techniques}

The descriptive and inferential statistics were employed. The descriptive statistics surveyed the mean and standard deviation of the variables. The regression analysis was employed to examine the impact and causal relationship of the variables. The significance or otherwise of the specific or isolated and joint (aggregate) effects of corporate governance measures on investors' decision variables were determined using T-statistics and F-statistics and their associated probability values, at 5\% level of significance. Adjusted coefficient of multiple determinations (Adjusted $\mathrm{R}^{2}$ ) was used as a measure of explanatory power of the various proxies of corporate governance in relation to investors' decision in deposit money banks. Also, post estimation tests were carried out to determine the appropriateness of the model estimations. These tests include serial correlation test, heteroscedasticity test and Breusch and Pagan Lagrangian multiplier test.

\section{Variable Description and Measurement}

The study adopted the following proxies to examine the effect of corporate governance on investors' decision in quoted deposit money banks in Nigeria.

TABLE 1: DESCRIPTION OF VARIABLE/MEASUREMENTS

\begin{tabular}{|c|c|c|}
\hline Variables & Abbreviation & Definition \\
\hline Board Size & BDS & Number of Directors on board \\
\hline Board Composition & $\mathrm{BDC}$ & $\begin{array}{l}\text { Proportion of independent } \\
\text { directors/ institutional } \\
\text { investors as members against } \\
\text { total number of directors }\end{array}$ \\
\hline Audit Quality & ADQ & $\begin{array}{l}1 \text { to represent the use of big } 4 \\
\text { and } 0 \text { if otherwise }\end{array}$ \\
\hline $\begin{array}{l}\text { Audit Committee } \\
\text { Expertise }\end{array}$ & $\mathrm{ACE}$ & $\begin{array}{l}\text { Presence/number of financial } \\
\text { experts in the audit committee }\end{array}$ \\
\hline $\begin{array}{c}\text { Volume of Shares } \\
\text { Traded }\end{array}$ & $\mathrm{V}_{\mathrm{o}} \mathrm{ST}$ & $\begin{array}{l}\text { The total quantity of shares } \\
\text { traded on a particular security } \\
\text { during a specified period of } \\
\text { time. }\end{array}$ \\
\hline Firm Size & FMS & $\begin{array}{l}\text { Natural } \log \text { of total assets of } \\
\text { the firm. }\end{array}$ \\
\hline Profitability & PRT & Earnings Per Share \\
\hline
\end{tabular}

Source: Researcher's Study, 2020.

\section{E. Model Specification}

The variables for the study were independent variables, dependent variables and control variables. The independent variable is Corporate Governance represented by Board Size (BDS); Board Composition (BDC); Audit Quality (ADQ) and Audit Committee Expertise (ACE). The dependent variable is Investors' Decision, represented by Volume of Shares Traded 
$\left(\mathrm{V}_{\mathrm{o}} \mathrm{ST}\right)$. The control variables are Firm Size (FMS) and Profitability (PRT).

This was represented as:

$$
\mathrm{Y}=\mathrm{f}(\mathrm{X})
$$

where:

$\mathrm{Y}=$ Investors' Decision variables represented by Volume of Shares Traded $\left(\mathrm{V}_{\mathrm{o}} \mathrm{ST}\right)$.

$\mathrm{X}=$ Corporate Governance.

$\mathrm{Z}=$ Control Variables.

$\mathrm{X}=\mathrm{x}_{1}, \mathrm{x}_{2}, \mathrm{x}_{3}, \mathrm{x}_{4}$.

$\mathrm{Z}=\mathrm{z}_{1}, \mathrm{z}_{2}$.

$\mathrm{x}_{1}=$ Board Size (BDS).

$\mathrm{x}_{2}=$ Board Composition (BDC).

$\mathrm{x}_{3}=$ Audit Quality (ADQ).

$\mathrm{x}_{4}=$ Audit Committee Expertise (ACE).

$\mathrm{z}_{1}=$ Firm Size (FMS).

$\mathrm{Z}_{2}=$ Profitability (PRT).

The models are as follows:

\section{Model 1:}

$$
\mathrm{V}_{\mathrm{o}} \mathrm{ST}_{\mathrm{it}}=\alpha_{1}+\beta_{1} \mathrm{BDS}_{\mathrm{it}}+\beta_{2} \mathrm{BDC}_{\mathrm{it}} \beta_{3} \mathrm{ADQ}_{\mathrm{it}}+\beta_{4} \mathrm{ACE}_{\mathrm{it}}+\mu_{\mathrm{it} 1}
$$

\section{Model 2:}

$$
\begin{gathered}
\mathrm{V}_{\mathrm{o}} \mathrm{ST}_{\mathrm{it}}=\alpha_{2}+\beta_{1} \mathrm{BDS}_{\mathrm{it}}+\beta_{2} \mathrm{BDC}_{\mathrm{it}}+\beta_{3} \mathrm{ADQ}_{\mathrm{it}}+\beta_{4} \mathrm{ACE}_{\mathrm{it}}+ \\
\beta_{5} \mathrm{FMS}_{\mathrm{it}}+\beta_{6} \mathrm{PRT}_{\mathrm{it}}+\mu_{\mathrm{it} 2}
\end{gathered}
$$

where:

$\alpha_{1-2}$ are the intercepts.

$\beta_{1-4}$ and $\beta_{1-6}$ for each model are the coefficients.

$\mu_{1-2}$ are the stochastic variables of each model.

'it' represents firm ' $i$ ' in time ' $t$ '.

\section{ANALYSIS, RESULTS AND DISCUSSION}

\begin{tabular}{ccccc}
\multicolumn{5}{c}{ TABLE 2: DesCRIPTIVE STATISTICS } \\
\hline $\mathrm{V}_{\mathrm{o}} \mathrm{ST}$ & 2.3519 & 2.437 & 0 & 9.1121 \\
BDS & 14.0667 & 3.7079 & 6 & 20 \\
BDC & 0.7703 & 1.1259 & 0 & 4 \\
ADQ & 0.90441 & 0.2951 & 1 & 1 \\
ACE & 1.1176 & 0.4047 & 1 & 2 \\
FMS & 0.4037 & 0.7056 & 0 & 3.4996 \\
PRT & 0.2470 & 15.6192 & -157.98 & 37.48 \\
\hline
\end{tabular}

Source: Researcher's Study, 2020.

Table 2 shows the summary statistics of all the variables obtained from the sampled banks for the period under study. Specifically, the mean values for traded volume stood at 2.35 shares, while the standard deviation was 2.437 shares. This depicts that there was not much fluctuation on the volume of shares. With respect to Board Size (BDS) however, the mean shown was about 14 while the standard deviation was about 3 . This suggests that there were some variations in the sizes of the board across the different sampled banks over the sampled period. Similar experience was also seen in profitability (PRT), the mean was 0.247 and the standard deviation was about 15 . The wide gap between the mean and the standard deviation showed that there were fluctuations in the profit recorded across the sampled banks over the sampled period. There were no wide gaps between the mean and standard deviations of Board Composition (BDC), Audit Quality (ADQ), Audit Committee Expertise (ACE) and Firm Size (FMS), this suggests that the sampled banks did not fluctuate much with respect to Board Composition (BDC), Audit Quality (ADQ), Audit Committee Expertise (ACE) and Firm Size (FMS) over the period selected for this study.

\section{A. Inferential Analysis}

1. Research Hypothesis $1\left(H_{o l}\right)$

Corporate governance does not have significant effect on

\begin{tabular}{|c|c|c|c|c|}
\hline Variable & Coefficient & Std Error & t-Stat. & Prob. \\
\hline Constant & .3454745 & .9738427 & -1.563222 & 2.254171 \\
\hline BDS & .0786032 & .0504568 & 1.56 & 0.119 \\
\hline $\mathrm{BDC}$ & .6254573 & .1985472 & 5 & $0.002 *$ \\
\hline ADQ & 1.066647 & .8091438 & 1.32 & 0.187 \\
\hline $\mathrm{ACE}$ & -.4632089 & .7011271 & -0.35 & 0.509 \\
\hline R-squared & 0.1029 & & & \\
\hline Adjusted R-squared & 0.0753 & & & \\
\hline F-Statistic & 13.43 & & & \\
\hline Prob.(F-Stat) & $0.0093^{*}$ & & & \\
\hline Breusch and Pagan & & & & \\
\hline $\begin{array}{c}\text { Lagrangian multiplier } \\
\text { test }\end{array}$ & 11.08 & & & $0.0004 *$ \\
\hline Heteroskedasticity Test & 5.23 & & & $0.0222 *$ \\
\hline $\begin{array}{l}\text { Wooldridge test for } \\
\text { autocorrelation }\end{array}$ & 4.740 & & & 0.0485 \\
\hline $\begin{array}{l}\text { Pesaran's test of cross- } \\
\text { sectional independence }\end{array}$ & 11.043 & & & $0.00 *$ \\
\hline
\end{tabular}
the volume of shares traded.

$$
\text { a. Model } 1
$$

TABLE 3: REGRESSION ANALYSIS FOR MODEL ONE

$$
\begin{aligned}
\mathrm{V}_{\mathrm{o}} \mathrm{ST}_{\mathrm{it}} & =0.3454+0.0786 \mathrm{BDS}_{\mathrm{it}}+0.6254 \mathrm{BDC}_{\mathrm{it}}+ \\
& 1.066 \mathrm{ADQ}_{\mathrm{it}}-0.463 \mathrm{ACE}_{\mathrm{it}}+\mu_{\mathrm{it} 1}
\end{aligned}
$$

\section{b. Findings}

The regression analysis estimates on Table 3 shows that Board Size (BDS), Board Composition (BDC) and Audit Quality (ADQ), have positive effects on the Volume of shares traded $\left(\mathrm{V}_{\mathrm{o}} \mathrm{ST}\right)$. This is indicated by the sign of the coefficients, that is $\beta_{1}=0.0786>0, \beta_{2}=0.6254>0$, and $\beta_{3}=1.066>0$ respectively. This result was to an extent largely consistent with a priori expectation as it was expected that the Corporate governance measured by Board Size (BDS), Board Composition (BDC) and Audit Quality (ADQ), will have a positive effect on Volume of shares traded $\left(\mathrm{V}_{\mathrm{o}} \mathrm{ST}\right)$. Audit Committee Expertise (ACE) was however inconsistent because there was a negative effect on Volume of shares traded $\left(\mathrm{V}_{\mathrm{o}} \mathrm{ST}\right)$. Also, the size of the coefficient of the independent variable showed that a 1 unit increase in BDS, BDC and ADQ, will lead to a 0.0786, 0.6254 and 1.066 unit increases in $\mathrm{V}_{\mathrm{o}} \mathrm{ST}$ respectively, while a 1 unit increase in ADQ will lead to a 0.463 unit decrease in $\mathrm{V}_{\mathrm{o}} \mathrm{ST}$. Furthermore, the probability of the t-statistics of 0.00 shows that the coefficient was statistically significant at $5 \%$ level of significant for BDC.

\section{c. Decision}

At the level of significance of 0.05 , the F-statistics is 13.43 while the P-value of the F-statistics is 0.0093 which is less than 0.05 . The null hypothesis that corporate governance does not have significant effect on the volume of shares traded was 
not accepted. This means there is a positive effect of corporate governance on the Volume of share traded $\left(\mathrm{V}_{\mathrm{o}} \mathrm{ST}\right)$ and this effect is statistically significant.

\section{Research Hypothesis $2\left(H_{o 2}\right)$}

Firm size and profitability do not significantly control the effect of corporate governance on the volume of shares traded.

\section{a. Model 2}

TABLE 4: REGRESSION ANALYSIS FOR MODEL TwO

\begin{tabular}{lcccc}
\hline \multicolumn{1}{c}{ Variable } & Coefficient & Std Error & t-Stat. & Prob. \\
\hline Constant & .4774359 & .9721034 & 0.49 & 0.623 \\
BDS & .0772182 & .0501148 & 1.54 & 0.123 \\
BDC & .5811937 & .2787501 & 2.08 & $0.037^{*}$ \\
ADQ & .9488667 & .8082735 & 1.17 & 0.240 \\
ACE & -.4671234 & .710295 & -0.66 & 0.511 \\
FMS & .0763296 & .2801553 & 0.27 & 0.785 \\
PRT & -.0193551 & .011191 & -1.73 & 0.084 \\
R-squared & 0.1079 & & &
\end{tabular}

Adjusted R-squared

$\begin{array}{ll} & 0.065 \\ \text { F-Statistic } & 20.15 \\ \text { Prob.(F-Stat) } & 0.0026\end{array}$

Prob.(F-Stat) $\quad 0.0026^{*}$

Lagrangian multiplier

test

Heteroskedasticity Test $\quad 6.63$

Wooldridge test for 4.789

autocorrelation

Pesaran's test of cross-

10.850

$0.0002 *$

sectional independence

Dependent Variable: VoST, *significant at 5\%.

Source: Researcher's Study, 2020.

$$
\begin{gathered}
\mathrm{V}_{\mathrm{o}} \mathrm{ST}_{\mathrm{it}}=0.477+0.077 \mathrm{BDS}_{\mathrm{it}}+0.581 \mathrm{BDC}_{\mathrm{it}}+0.948 \mathrm{ADQ}_{\mathrm{it}}- \\
0.467 \mathrm{ACE}_{\mathrm{it}}+0.076 \mathrm{FMS}_{\mathrm{it}}-0.019 \mathrm{PRT}_{\mathrm{it}}+\mu_{\mathrm{it} 1}
\end{gathered}
$$

\section{b. Findings}

The regression analysis estimates on Table 4 showed that Board Size (BDS), Board Composition (BDC), Audit Quality (ADQ) and Firm Size (FMS), have joint and positive effects on the Volume of shares traded $\left(\mathrm{V}_{\mathrm{o}} \mathrm{ST}\right)$. This is indicated by the sign of the coefficients, that is $\beta_{1}=0.077>0, \beta_{2}=0.581>$ $0, \beta_{3}=0.948>0$ and $\beta_{5}=0.076>0$ respectively. Audit Committee Expertise (ACE) and Profitability (PRT) however have a negative effect on Volume of shares traded $\left(\mathrm{V}_{\mathrm{o}} \mathrm{ST}\right)$ as indicated in Table 4 , which is also indicated by the sign of the coefficient $\beta_{4}=-0.467<0$ and $\beta_{6}=-0.019<0$. Thus, the introduction of control variables of firm size and profitability brought changes in the basic statistics as shown in Table 4 ( $F$ $(6,126)=20.15$; Adj. $\left.R^{2}=0.0654 ; p=0.0026\right)$. This result was to an extent largely consistent with a priori expectation as it was expected that the Corporate governance measured by Board Size (BDS), Board Composition (BDC), Audit Quality (ADQ) and Firm Size (FMS), will have a positive effect on Volume of shares traded $\left(\mathrm{V}_{\mathrm{o}} \mathrm{ST}\right)$. Audit Committee Expertise (ACE) and Profitability (PRT) were however inconsistent because there was a negative effect on Volume of shares traded $\left(\mathrm{V}_{\mathrm{o}} \mathrm{ST}\right)$. Also, the size of the coefficients of the independent variable showed that a 1 unit increase in BDS, BDC, ADQ and FMS, will lead to a 0.0772, 0.581, 0.948 and 0.076 unit increase in $\mathrm{V}_{\mathrm{o}} \mathrm{ST}$ respectively, while a 1 unit increase in ADQ and PRT will lead to a 0.467 and 0.019 unit decrease in $\mathrm{V}_{\mathrm{o}} \mathrm{ST}$. Furthermore, the probability of the tstatistics of 0.037 shows that the coefficient was statistically significant at $5 \%$ level of significant for BDC.

\section{c. Decision}

At the level of significance of 0.05 , the F-statistics was 20.15 while the P-value of the F-statistics was 0.0026 which was less than 0.05 . From the result of the regression analysis, firm size and profitability significantly controlled the effect of corporate governance on volume of shares traded. Therefore, the null hypothesis $\left(\mathrm{H}_{01}\right)$ which said Firm size and profitability do not significantly control the effect of corporate governance on the volume of shares traded was rejected.

\section{B. Discussion of Findings}

The regression estimates of Model 1 showed that Board Size (BDS), Board Composition (BDC) and Audit Quality (ADQ), have joint and significant influence on Volume of Shares Traded $\left(\mathrm{V}_{\mathrm{o}} \mathrm{ST}\right)$ of quoted deposit money banks in Nigeria. This finding aligned with Amarjit, Suraj, Harvinder and Neil [93] who found positive relationship between corporate governance and investment decision of small business firms in Indian manufacturing industry using board size and firm performance. Also, in a related study, Jaafar and El- Shawa [94] found that "board size has a positive and significant impact on firm performance" which agreed with the result of findings in model 1 . This result was also consistent with the a priori expectation that Board Size (BDS), Board Composition (BDC), and Audit Quality (ADQ) would have a positive effect on investors' decision measured by Volume of Shares Traded $\left(\mathrm{V}_{\mathrm{o}} \mathrm{ST}\right)$ of quoted deposit money banks in Nigeria. Audit Committee Expertise (ACE) negates the $a$ priori expectation. The adjusted R-squared indicates that the independent variables explained about $7.53 \%$ of the variation in Volume of Shares Traded $\left(\mathrm{V}_{\mathrm{o}} \mathrm{ST}\right)$ while the remaining $92.5 \%$ variations were caused by other factors not included in the model. Although the result was consistent with the a priori expectation, the findings of this study align with the findings of Carcello and Neal [95].

The regression estimates of Model 2 showed that Board Size (BDS), Board Composition (BDC), Audit Quality (ADQ) and Firm Size (FMS) have positive effects on the Volume of share traded $\left(\mathrm{V}_{\mathrm{o}} \mathrm{ST}\right)$. This result explains the controlling effect of firm size on other corporate governance measures and it shows that the relationship is positive and statistically significant. This agrees with Jelic, Briston and Ausseng [38] and Kakani, Saha and Reddy [39] who explained the importance of scale economies and other efficiencies in larger firms. This result is consistent with the a priori expectation that Board Size (BDS), Board Composition (BDC), and Audit Quality (ADQ) and Firm Size (FMS) have a positive effect on investors' decision measured by Volume of Shares Traded $\left(\mathrm{V}_{\mathrm{o}} \mathrm{ST}\right)$ of quoted deposit money banks in Nigeria, while Audit Committee Expertise (ACE) and Profitability (PRT) negated the a priori expectation.

Again, the adjusted R-squared shows that about $6.54 \%$ variations in Volume of Shares Traded $\left(\mathrm{V}_{\mathrm{o}} \mathrm{ST}\right)$ is explained by the independent and control variables while the remaining $93.5 \%$ variations were caused by other factors not included in the model. The result was consistent with the a priori expectation and also aligned with the findings of De Medeiros, Doornik and Bernardus [77] documented that "there is a contemporaneous as well as dynamic relationship 
between stock returns, trading volume and good governance".

\section{CONCLUSION AND RECOMMENDATIONS}

The study examined Corporate Governance and investors' decision in quoted deposit money banks in Nigeria. Numerical description of all variables under study was captured to depict the movement of values and determine the fluctuations of each of the independent variables with the dependent variables. The study documented evidence that corporate governance affects volume of shares traded and firm size and the profitability of the firms have controlling influence on the corporate governance - volume of shares traded relationship.

Based on the findings and conclusions of the study, the following recommendations were made to top executives of organizations, regulators, stock brokers, capital market operators, business managers and shareholders/investors.

Top executives/management and board of directors should entrench sound corporate governance practices in their business operations to attract more investors and enhance the volume of their shares traded on the exchange.

Investors should consider firm size of the company they intend investing in. Larger firm enjoys economy of scale and efficiency. The size of an enterprise affects different things in the business such as the goodwill, customer loyalty, patronage as well as its level of responsiveness to the stakeholders

Management and board of directors should imbibe transparent corporate governance culture in their organization. This will attract investors to their organizations when making investment decision in shares. The adoption of good corporate governance practices will promote good governance that will increase value of shares traded.

In the short run, management's goal should be the entrenchment of structures, line of responsibility, accountability and provision of information to stakeholders towards building an organization that will be attractive to investors and profitable in the long run.

\section{REFERENCES}

[1] Masomi, S. R. \& Ghayekhoo, S. (2011). Consequence of human behaviours in economic: the effects of behavioural factors in investment decision making at Tehran Stock Exchange. International Conference on Business and Economic Research (pp. 234-237). Kuala Lumpur, Malaysia: IACSIT Press.

[2] Olafsson, S. (2003). Marketing decisions under uncertainty implications for high technology investments. BT Technology Journal, 21(2), 170-174.

[3] Pandey, I. M. (2015). Essentials of financial management, 4th edition. Lagos: Vikas Publishing House.

[4] Owolabi, S. A, Olotu, A. \& Owolabi, T.J. (2014). Strengthening corporate governance: the role of Internal Audit. Journal of Corporate Governance, 6(3), 1260-1283.

[5] Anthony, R. N. (2007). The trouble with project maximazation. The firm as an entity: Implication for economics, accounting and law; Routledge, ISBN 978-0-415-41443-2, pp. 201-215.

[6] Onyenankeya, K. (2003, January 1). Financial crimes: the Nigerian experience. Nigerian Stock Market Annual Report, pp. 25-33.

[7] Kajola, S. O. (2008). Corporate governance and firm's performance: The case of Nigerian listed firms. European Journal of Economic, Finance and Administrative Sciences, 14. Retrieved from https://www.eurojournals.com.
[8] Owolabi, S. A. (2018). Corporate governance and performance: A pathological exposition of Nigerian firms. 21st Inaugural Lecture (pp. 1-73). Ilishan-Remo: Babcock University Press.

[9] Ajayi, M. (2005). Banking sector reforms and bank consolidation: conceptual framework. Bullion, 29(2), 15-28.

[10] Okaro, S. Okafor, G.O. \& Ofoegbu, G.N. (2013). The effect of joint audit on audit quality. The perception of accountants, auditors and accounting acedemics at AAFA 2015 conference in Mauritius, 2015. DOI:10.13140/RG.2.1.2695.6009.

[11] Fabian, A. S. (2010). Corporate governance and ethical business dealings in Nigeria: The imperatives. Journal of Corporate Governance, 2(1), 211.

[12] Vogel, D. (2017). Corporate social responsibility: challenges. The Tokyo Foundation, 4(1), 16-21.

[13] International Finance Corporation. (2010). Corporate governance manual (2nd ed.). Vietnam: Bacson

[14] Cadbury, A. (2002). Corporate governance \& chairmanship: A personal view. USA: Oxford University Press.

[15] Surya, B. G. (2016). Corporate governance and firm performance: emperical evidence from India. Journal of Business and Management Research, 1(2), 48-65.

[16] Kayode, O. (2012). The governance issues in Nigeria's financial liberation. The Chartered Secretary and Administrator, IX (20), 5.

[17] Onyema, O. N. (2018, February 22). NSE CEO keynote address at the certification ceremony of the Corporate Governance Rating System. Lagos, Nigeria.

[18] Onyema, O. (2018). NSE launches corporate governance index. Retrieved from https//nipc.gov.ng/2018/02/26/nselaunches.corporate-index, December 14, 2019.

[19] Khaliq, U.R.C \& Muhammed, S.D. (2013). Impact of corporate governance on performance of firms: A case study of cement industry in Pakistan. Journal of Business and Management Sciences. 4(1), 4446.

[20] Ferreira, V. D. (2014, October 31). Corporate governance and its influence on the investment decision process of equity markets profession: An inside view of how corporate governance influence the decision making process of sell-side and buy-side professionals when analyzing Brazilian coy. Rio de Janeiro. Retrieved from https://bibliotcadigital.fgv.br/.../bitstream/...vicente\%20ferreira\%20$\% 20$, Brazil.

[21] Adekunle, S. A. \& Aghedo, E. M. (2014). Corporate governance and financial performance of selected quoted companies in Nigeria. European Journal of Business and Management, 6(9). Retrieved from https:/www.researchgate.net/publication/290814265.

[22] Agbaeze, E.K. \& Ogosi, C.D. (2018). Corporate governance and profitability for Nigerian banks. European Journal of Scientific Research, 148(3), 358-367.

[23] Slater, F. S. \& Zwirlein, T. J. (1996). The structure of financial strategy: Patterns in financial decision-making. Journal of managerial and business economies, 17(3), 253-266.

[24] Okere, W. \& Ibidunni, O. (2019). Corporate governance and investment decisions in deposit money banks in Nigeria. International Journal of Management, Accounting and Economics, 6(3), 237-257.

[25] Osuoha, J. (2004). Principles and practice of stockbroking, 1st edition. Lagos: God's Grace Publishers.

[26] Mohammed, W.S. \& Elewa, M. M. (2016). The impact of corporate governance on stock price and trade volume. International Journal of Accounting and Financial Reporting 6(2), 27-44.

[27] Ekundayo, V. (2012). Corporate governance: It's not just about having an improved Corporate governance code. The Chartered Secretary and Administrator: The Institute of Chartered Secretaries and Administrators of Nigeria, IX (20), 18-23.

[28] Daily, C. M. \& Dalton, D. R. (1992). The relationship between governance structure and corporate performance in entrepreneural firms. Journal of Business Venturing, 7(5), 375-386.

[29] Daily, C. M. \& Ellstrand, A. (1996). Boards of directors: A review and research agenda. Journal of Management, 22(3), 409-418.

[30] Rosenstein, S. \& Wyatt, V. (1997). Outside directors, board effectiveness and shareholders wealth. Journal of Finance Economics, 26, 175-191.

[31] Ramon, V. R. (2001). Corporate governance as competitive advantage in Asia: managing corporate governance in Asia. Asia Institute of Management, Philippines, 1(4), 18-34.

[32] Wheelen, T.L \& Hunger, J.D. (2006). Strategic management and business policy. (10th ed.). United State of America: Pearson Prentice Hall.

[33] Fama, E.F. \& Jensen, M.N. (1983). Separation of ownership and control. Journal of Law and Economics, 26, 301-325. 
[34] Clarkson, R. \& Deck, A. (1997). Effective governance of micro finance industry: estimating a micro finance industry. Journal of Finance Economics; 26, 67-75.

[35] Okeahalam, C. \& Akinboade, A. (2003, June 15). A review of corporate governance in Africa: literature, issues and challenges, Paper prepared for the Global Corporate Governance Forum. Global Corporate Goverance Forum, pp. 10-21.

[36] McGee, R. (2009). Corporate governance in developing economies: Country studies of Africa, Asia and Latin America. Retrieved from https/link.spinger.com/book/10.1007/978-0-387-84833-4, 3-22.

[37] Babalola, Y. (2013). The effect of firm size on firm's profitability in Nigeria. Journal of Economics and Sustainable Development 4(5), 90 94.

[38] De Medeiros, M., Briston, R. \& Aussenegg, W. (2001). The finiancial performance of privatized firms: Evidence from three transition economies. Journal of Business Finance \& Accounting 7(4), 9-25.

[39] Kakani, R. Saha, B. \& Reddy, V. (2001). Determinants of financial performance of India corporate sector in the post liberalization era: An exploratory study. NSE Research Initiative Papers (5), 12-30.

[40] Dogan, M. (2013). Does firm size affect the firm profitability? Evidence from Turkey. Research of Journal of Finance and Accounting, 4, 53-59.

[41] Majumdar, S. (1997). The impact of size and age on firm-level performance: Some evidences from India. Review of Industrial Organization 12(2), 231-241.

[42] Lipton, M. \& Lorsch, J. W. (1992). A modest proposal for improved corporate governance. Business Lawyer, 48(1), 59-77.

[43] Yermack, D. (1996). Higher market valuation of companies with a small board of directors. Journal of Financial Economics, 40(2), 185211.

[44] Dalton, D., Daily, C., Johnson, J. \& Ellstrand, A. (1999). No. of Directors and financial performance: A metal-analysis. Academy of Management Journal (42), 674-686.

[45] Dalton, D., \& Dalton, C. R. (2005). Boards of directors: Utilizing emperical evidence in developing practical prescriptions. British Journal of Management (16), 91-97.

[46] Jensen, M. C. (1993). The modern industrial revolution, exit, and the failure of internal control systems. Journal of Finance (48), 831 - 880

[47] Sanda, A. U., Mikailu, A. S. \& Garba A. (2005). Corporate governance mechanisms and firm financial performance in Nigeria AERC Research Paper, 149-157.

[48] Hermalin, B. E. \& Weisbach, M. S. (1991). The effects of board composition and direct incentives on firm performance. Journal of Financial Management 20(4), 101-112.

[49] Klein, A. (1998). Firm performance and board committee structure. The Journal of Law and Economics (41), 275-304.

[50] Bhagat, S. \& Bolton, B. (2008). Corporate govervance and firm performance. Journal of Corporate Finance, 14(3), 257-273.

[51] Li, W.A. \& Li, B. (2008). An emperical study of the impact of institutional shareholders on corporate governance. Journal of Nankai Business Review, 11(1), 4-14.

[52] Hartzell \& Starks. (2000). Institutional investors and executive compensation working paper. Austin: New York University and University of Texas.

[53] DeAngelo, L. (1981). Audit size and audit quality. Journal of Accounting and Economies, 3, 183-199.

[54] Palmrose, Z. (1988). An analysis of auditor litigation and audit service quality. The Accounting Review, 64(1), 55.

[55] Abbott, L.J. \& Peters, G.F. (2004). Audit committee characteristics and restatements. Journal of Practice \& Theory (March), 69-87.

[56] Agrawal, A. \& Chadha, S. (2005). Corporate governance and accounting scandals. Journal of Law and Economics (October), 371 406.

[57] Anderson, R.C., Nansi, S. A. \& Reeb, D.M. (2004). Board characteristics, accounting report integrity and the cost of debt. Journal of Accounting and Economics (September), 315-342.

[58] Bedard, J.S., Chtourou, M. \& Courteau, L. (2004). The effect of audit committee expertise, independence and activity on aggressive earnings management. Auditing: A Journal of Practice \& Theory (September), 13-35

[59] Davidson, W.N., Xie, B. \& Xue, W. (2004). Market reaction to voluntary announcements of audit committee appointments: The effect of financial expertise. Journal of Accounting and Public Policy (July/August), 279-293.

[60] DeFond, M.L., \& Francis, J.R. (2005). Audit Research after SarbanesOxley. Auditing: A Journal of Practice \& Theory (Supplement), 5-30.

[61] Salehi, M., Moradi, M. \& Paiydarmaneshi, N. (2017). The effect of corporate governance and audit quality on disclosure quality: Evidence from Tehran Stock Exchange. Periodical Polytechnia Social and Management Sciences, 25(1), 32-48.
[62] Klein, A. (2002). Audit committee, board of directors characteristics and earnings management. Journal of Accounting and Economics, 33(3), 375-400

[63] Baxter, P., \& Cotter, J. (2009). Audit committees and earnings quality. Accounting and Finance, 49(2), 267-290.

[64] Hamdan, A. Sameh, A \& Reyed, R. (2013). The impact of audit committee characteristics on performance: evidence from Jordan International Management Review, 9(1), 32-42.

[65] Alzoubi, E. S. (2016). Audit quality and earnings management: Evidence from Jordan. Journal of Applied Accounting Research 17 170-187.

[66] Ammar, A., Muhammad, S. \& Muhammad, A. H. (2018). Do big four auditors always provide higher audit quality? Evidence from Pakistan. International Journal of Financial Studies 6(58), 1-22.

[67] Jensen, M.C., \& Meckling, W. H. (1976). Theory of the firm: managerial behaviour, agency costs and ownership structure. Journal of Financial Economics, 3(4), 305-360.

[68] Freeman, R. E. (1984). Strategic Management: A Stakeholder Approach. Boston: Pitman Publishing Inc.

[69] Effiok, S. O., Effiong, C. \& Usoro, A. A. (2012). Corporate governance, corporate strategy and corporate performance: Evidence from the financial institutions listed on the Nigerian Stock Exchange. European Journal of Business and Management, 4(18).

[70] Ambrose, J. \& Mutswenje, V. S. (2014). A survey of the factors influencing investment decisions: The case of individual investors at the NSE. International Journal of Humanities and Social Science, 4(4), 92-102.

[71] Reena, R. (2014). Factors affecting investors' decision making behaviour in the stock market: An analytical review. India Journal of Applied Research, 4(9), 118-120.

[72] Bistrova, J. Lace, N. \& Tvaronaviciene, M. (2014). Corporate governance as a factor for investment decision making on CEE equity markets. 18th World Multi-Conference on Sematics, Cybermetics an Informatiics (pp. 1 - 6). United State of America, Orlando: Institute of Informatics and Systemics.

[73] Obamuyi, T. M. (2013). Factors influencing investment decisions in capital market: A study of individual investors in Nigeria. Organisations and Markets in Emerging Economies, 4(7).

[74] Collince, O. G. (2010). The relationship between trading volume and price volatility of shares in the Nairobi Security Exchange. retriieved on October 27, 2019 from https://www.academia.educ/12522346.

[75] Llorente, M., Guillermo, J. Roni, M., Gideon, S. \& Jiang, W. (2002). Dynamic volume-return relationship of individual stock. Review Financial studies, 15, 10051047.

[76] Tauchen, G. E. \& Pitts, M. (1983). The price variability - volume relationship on speculative markets. Econometrica, 4850505.

[77] De Medeiros, O.R., Doormik, V. \& Bernardus, F.N. (2006). The emperical relationship between stock returns, return volatility and trading volume in the Brazilian stock market. Retrieved on November 27, 2019 from http/ssm.com/abstract=897340.

[78] Dumitrescu, A. (2010). Corporate governance and market liquidity. Financial Accounting and Reporting Journal Research, 48, 423 - 471.

[79] Foo, Y. B. \& Zain, M. M. (2010). Board independence, board diligence and liquidity in Malaysia: a research note. Journal of contemplorary Accounting and Economics, 6(2), 92-100.

[80] Obigbemi, I.F., Iyoha, F.O. \& Ojeka, S.A. (2015). Firm size and financial performance: A determinant of corporate governance disclosure practices of Nigerian companies. Journal of Accounting and Auditing Research \& Practice, 2015(2015), 1-8.

[81] Umoren, A. \& Okougbo, P. (2011). Comporate governance, company attributes and voluntary disclosure. A study of Nigerian listed companies. International Journal of Research in Computer Application \& Management 1(2), 20-30.

[82] Wahyuni, P. (2019). Good corporate governance and firm size on cost of debt. Evidence from Indonesian listed copanies. International Journal of Academic Research in Accounting, Finance and Management Sciences, 9(2), 257-265.

[83] Baumol, W. (1967). Business behaviour, value and growth. New York: Harcourt Brace Jovanorich.

[84] Simon, L. (1962). Size, strength and profit proceedings. Society Arlington, XLIX, 41-48.

[85] Hall, M. \& Weiss, L. (1967). Firm size and profitability. The Review of Economics and Statistics, 49(3), 319-331.

[86] Whittington, G. (1980). The profitability and size of United Kingdom companies. The Journal of Industrial Economics, 28(4), 335-352.

[87] Chandler, A. D. (1990). Strategy and structure: Chapters in the history of the industrial enterprise. MIT: Cambridge Press.

[88] Ravenscraft, D.J. \& Scherer, F.M. (1989). The profitability of mergers. International Journal of Industrial Organization, 7(1), 101116. 
[89] Prusty, T. \& Ah-ahdal, W.M. (2018). Corporate governance and profitability: Evidence from Indian IT companies. Financial Markets Institutions and Risks, 2(3), 68-75.

[90] Tabash, M.I., Yahya, A.T. \& Akhtar, A. (2017). Financial performance comparison of islamic and conventional banks in the United Arab Emirates (UAE). International Conference on Advances in Business, Management and Law, 2017, 477-494.

[91] Rashid, Z., Muhammad, A. \& Muhammad, A. S. (2015). Corporate governance and firm performance: The role of transparency and disclosure in banking sector of Pakistan. International Journal of Social and Humanistic Sciences, 43, 152-166.

[92] Kerlinger, F.N. \& Rint, N. (1986). Foundations of Behaviour Research. New York: Winston Inc.

[93] Amarjit, G., Suraj, S., Harvinder, S. M. \& Neil, M. (2012). The relationship between corporate governance and the investment decision of small business firms in India. Journal of Finance and Investment Analysis, 1(2), 41-59.

[94] Jaafar, A. \& El-Shawa, M. (2014). Ownership concentration, board characteristics and performance: Evidence from Jordan, in Tsamenyi, M. \& Uddin, S. (Eds). Accounting in emerging Economics (Research in Accounting in Emerging Economies), 9, 73-95.

[95] Carcello, J.V. \& Neal, T. L. (2003). Audit committee characteristics and audit dismissals following new going concern reports. Accounting Review, 95-117. 